DOI: 10.32844/2222-5374-2020-104-2.19

УДК: 342.951+35.078

Князюк О. Г.,

здобувач Науково-дослідного інституту публічного права

\title{
ОСОБЛИВОСТІ ПРАВОВИХ ЗАСАД НАДАННЯ АДМІНІСТРАТИВНИХ ПОСЛУГ СЕРВІСНИМИ ЦЕТРАМИ МВС УКРАЇНИ
}

Зазначено, що створення сервісних центрів МВС України було одним із напрямків реформування органів внутрішніх справ. Разом з тим, порівняно нетривалий час існування останніх обумовлює необхідність оцінки сучасного стану правових засад надання адміністративних послуг відповідними центрами. Автор приділяє безпосередню увагу теоретичним засадам розуміння категорій «правові основи», «правові засади», «правове регулювання», «адміністративно-правове регулювання», "адміністративно-правові засади». У статті розглянуто зміст нормативно-правових актів, шо регулюють суспільні відносини у сфері надання адміністративних послуг сервісними центрами МВС України залежно від рівня їх правового регулювання: законодавчий, підзаконний, відомчий. Як результат проведений аналіз правових засад надання адміністративних послуг сервісними центрами МВС України надав можливість охарактеризувати їх наступними ознаками (особливостями): визначають зміст діяльності сервісних иентрів МВС України як складової сервісної функції держави; їх систему складають норми Конституції України, міжнародних правових актів, ратифікованих Верховною Радою України, законів України, підзаконних та відомчих нормативно-правових актів; мають дуалістичну природу, що проявляється у регулюванні суспільних відносин даної сфери нормами конституційного та адміністративного права; законодавчий рівень правового регулювання встановлює титульні засади щодо надання адміністративних послуг загалом та сервісними центрами МВС України зокрема, вимоги до окремих об'єктів адміністративних послуг, що надаються сервісними центрами МВС України, зміст прав та інтересів фізичних та юридичних осіб і умови їх реалізації, кінцевим етапом яких є надання адміністративних послуг сервісними центрами МВС України; правові засади підзаконного рівня правового регулювання, уособлюючи норми правових актів Кабінету Міністрів України, конкретизують положення законів або регламентують відносини, які не входять до предмету законодавчого регулювання; нормативно-правові акти відомчого рівня правового регулювання переважно деталізують окремі аспекти процедур надання адміністративних послуг сервісними центрами МВС України; титульні правові засади поєднують положення законодавчого та достатньо непослідовний «симбіоз» підзаконного та відомчого рівнів правового регулювання.

Ключові слова: правові засади, правове регулювання, адміністративно-правове регулювання, норми права, сервісні центри МВС України. 
Актуальність теми. Становлення України як європейської правової держави нерозривно пов'язано з перманентним удосконаленням правового регулювання суспільно-політичного життя. Непересічне значення у даному аспекті займає сфера надання адміністративних послуг, яка уособлює сервісний зміст діяльності держави по відношенню до її громадян. Необхідно констатувати, що реальна сервісна діяльність суб'єктів публічної адміністрації України є досягненням лише останніх років. Зокрема створення сервісних центрів МВС України було одним із напрямків реформування органів внутрішніх справ. Разом з тим, порівняно нетривалий час існування останніх обумовлює необхідність оцінки сучасного стану правових засад надання адміністративних послуг відповідними центрами.

Стан дослідження. Питанням загальнотеоретичного правового регулювання приділили свою увагу С.С. Алексєєв, М.С .Кельман, В.В. Копєйчиков, А.М. Колодій, О.Ф. Скакун, В.А. Хропанюк, І.М. Шопіна та багато інших провідних науковців.

Дослідження окремих питань правового регулювання надання адміністративних послуг проводили такі вчені, як: В.Б. Аверянов, О.Ф. Андрійко, В.М. Бесчастний, І.П. Голосніченко, А.В. Капуловський, І.Б. Коліушко, О.В. Кузьменко, М.С. Міхровська, І.М. Рассоха, В.П. Тимочук. Разом з тим праці зазначених вчених торкаються проблем правових засад надання адміністративних послуг сервісними центрами МВС України побічно у розрізі вирішення інших теоретичних та практичних питань.

Мета статті полягає у оцінці сучасного стану правових засад надання адміністративних послуг сервісними центрами МВС України шляхом окреслення їх ключових ознак (особливостей).

Виклад основного матеріалу. Представники теорії держави та права під категорією «правове регулювання» переважно розуміють здійснюване державою за допомогою права та сукупності правових засобів упорядкування суспільних відносин, їх юридичне закріплення, охорона і розвиток $[1$, с. 529$]$.

В свою чергу правові основи (засади) тієї чи іншої сфери суспільної діяльності розглядаються переважно як сукупність норм права або сукупність певного переліку нормативно-правових актів. Для прикладу можемо привести, зокрема такі: правові засади являють собою сукупність прийнятих владою законів, кодексів, підзаконних актів, що мають закріплювати демократичні основи, які визнані багатьма державами світу і $є$ основою певного виду діяльності» [2, с. 283]; правова основа втілює сукупність правових норм, що регулюють суспільні відносини, які виникають у процесі організації й функціонування органів публічної влади, закріплюють елементи їх організації і діяльності» [3, с. 55].

Галузева належність правових засад (правового регулювання) надання адміністративних послуг засвідчує необхідність звернення до предмету та методу правового регулювання. Така позиція є загальноприйнятою у теорії права.

Аналіз сучасної наукової та навчальної юридичної літератури дають підстави зробити висновок, що основними серед правових засад надання адміністративних послуг виступають норми адміністративного права (адміністративного законодавства). Так, грунтовне розуміння сучасного пред- 
мету та методу адміністративного права можна знайти у роботах Т.О. Коломоєць. Зокрема вчена зазначає, що: «предметом адміністративного права $\epsilon$ суспільні відносини, що формуються» [4, с. 4] у тому числі «у діяльності органів виконавчої влади ... , їх посадових осіб щодо забезпечення реалізації та захисту прав і свобод громадян, надання їм, а також юридичним особам різноманітних адміністративних послуг» [4, с. 4]; «поряд із переважним застосуванням імперативного методу в адміністративно-правовому регулюванні суспільних відносин здійснюється використання і певних елементів диспозитивного методу (надання адміністративних послуг, укладення адміністративних договорів тощо) ... » [4, с. 5-6].

Як зазначає I.M. Шопіна, адміністративно-правове регулювання являє собою адміністративно-правовий вплив, здійснюваний за допомогою комплексу адміністративних засобів та інших правових явищ, які в сукупності складають механізм адміністративно-правового регулювання [5, с. 33].

Поняття механізму правового регулювання - одне з центральних у правовій науці. На думку І.П. Голосніченко, механізм адміністративно-правового регулювання являє собою сукупність адміністративно-правових засобів, за допомогою яких здійснюється вплив на відносини, що виникають у процесі реалізації державної виконавчої влади [6, с. 14]. Слушною $€$ позиція В.В. Коваленка, згідно якої найважливішим засобом механізму адміністративно-правового регулювання виступає «норма права» [7, с. 78].

Заслуговує окремої уваги дослідження категорії «адміністративно-правові засади», проведене Д.Г. Забродою, відповідно до якого автор пропонує адміністративно-правові засади визначити як сукупність закріплених у нормах адміністративного права параметрів (характеристик) суспільного явища та правовідносин, що потребують урегулювання за допомогою адміністративно-правових засобів. У змісті адміністративно-правових засад пропонується виокремлювати категоріальний; нормативний; інституційний; інструментально-технологічний елементи [8]. 3 приводу описаної точки зору підтримаємо В.О. Негодченка, який зазначає, що «... такий підхід не зовсім повно відображає специфіку правового регулювання, що має знаходитись в основі визначення правових засад, не враховує повною мірою вирішальність нормативного елементу для врегулювання правовідносин» [9, с. 101], які виникають, зокрема, у сфері надання адміністративних послуг сервісними центрами МВС України.

Як бачимо, описані підходи до розуміння категорій «правові основи», «правові засади», «правове регулювання», «адміністративно-правове регулювання», «адміністративно-правові засади» переважно зводиться до основоположного значення правових норм, які виступають основою механізму правового регулювання (його головним елементом); втілення правових засад, основ тощо.

В свою чергу зміст реалізації механізму правового регулювання полягає у наступному: «а) механізм правового регулювання містить у собі правові норми; б) реалізація правових норм відбувається у межах певних правовідносин; в) правові відносини набувають своєї сутності за наявністю певних юридичних фактів (життєвих обставин або підстав для здійснення певних вчинків); г) юридичні факти закріплені у гіпотезі правових норм»[10]. 
Норми права - це обов'язкове, формально визначене, цілісне, логічно завершене правило загального характеру, що відповідає визнаній у суспільстві мірі свободи, рівності та справедливості, встановлене чи санкціоноване державою або іншим уповноваженим суб'єктом правотворчості з метою регулювання суспільних відносин та забезпечується ними, включаючи можливість застосування примусу [11, с. 205].

Норми права містяться, головним чином, у нормативних актах - офіційних документах органів державної законодавчої або виконавчої влади правотворчого характеру.

Провідне значення для формування правових засад надання адміністративних послуг сервісними центрами МВС України відіграє Конституція України [12]. Особливе значення останньої у системі законодавства України традиційно визначається її верховенством та вищою юридичною силою, прямою дією, застосуванням на всій території країни, що безпосередньо випливає зі змісту положень ст. 8 Основного Закону нашої держави [12]. Як уявляється, віднесення Конституції України до правових засад надання адміністративних послуг сервісними центрами МВС України дещо суперечить отриманим нами висновкам щодо галузевої належності норм права (законодавства), які регламентують описувану сферу суспільних відносин. Втім така суперечність може видатися об'єктивною лише на перший погляд. Надзвичайно вдалою у даному аспекті необхідно визнати позицію Р.С. Мельника та В.М. Бевзенко, які зазначають, що «Конституція України у відповідних статтях, частинах статей тощо є джерелом для усіх галузей національного права. Проте найбільша кількість ії положень становить джерельну базу саме адміністративного права» [13, с. 91]. Більше того вчені приходять висновку, що «усі її розділи тією чи іншою мірою є, по-перше, основою для формування норм адміністративного права, по-друге, - правилами, якими у своїй діяльності мають безпосередньо керуватися суб'єкти публічної адміністрації» [13, с. 91].

Тож, правові засади надання адміністративних послуг сервісними центрами МВС України містяться зокрема у наступних конституційних нормах: 1) ст. 3, відповідно до якої «Людина, її життя і здоров'я, ... безпека визнаються в Україні найвищою соціальною цінністю. Права і свободи людини та їх гарантії визначають зміст і спрямованість діяльності держави. ... Утвердження і забезпечення прав і свобод людини є головним обов'язком держави» [12]; 2) ст. 6 - органи виконавчої влади здійснюють свої повноваження у встановлених Конституцією України межах і відповідно до законів України» [12]; 3) ст. 19 - «Правовий порядок в Україні грунтується на засадах, відповідно до яких ніхто не може бути примушений робити те, що не передбачено законодавством. Органи державної влади та органи місцевого самоврядування, їх посадові особи зобов'язані діяти лише на підставі, в межах повноважень та у спосіб, що передбачені Конституцією та законами України» [12].

Якщо розглядати діяльність сервісних центрів МВС України у розрізі, як приклад, видачі дозволів на перевезення небезпечних вантажів, погодження конструкцій транспортних засобів, надання права на керування транспортними засобами, які необхідно вважати джерелом підвищеної небезпеки, до правових засад надання ними адміністративних послуг уяв- 
ляється за можливе також віднести положення ст. 92 Конституції України: «виключно законами України визначаються основи національної безпеки, ... і забезпечення громадського порядку [12] (п. 17), ст. 116 - Кабінет Міністрів України, зокрема, здійснює заходи щодо забезпечення національної безпеки України, громадського порядку [12] (п. 7).

Крім зазначеного Конституція України дає нам підгрунтя вести мову про виокремлення наступного щаблю правових засад надання адміністративних послуг сервісними центрами МВС України, який закріплено на рівні міжнародних договорів, згоду на обов'язковість яких надано Верховною Радою України. Відповідно до положень ст. 9 Основного Закону держави такі документи $\epsilon$ «частиною національного законодавства України» [12].

Частиною 2 ст. 19 Закону України «Про міжнародні договори України» встановлено пріоритет міжнародно-правових норм над національними. Разом з тим Конституція України все ж залишає за собою найвищу юридичну силу серед усіх нормативно-правових актів нашої держави, адже ст. 9 передбачено, що «укладення міжнародних договорів, які суперечать Конституції України, можливе лише після внесення відповідних змін до Конституції України» [12]. Саме це і обумовлює розгляд міжнародних договорів, умовно кажучи, на «другому щаблі» правового регулювання, зокрема щодо надання адміністративних послуг сервісними центрами МВС України.

До міжнародних нормативно-правових актів, які містять засади надання адміністративних послуг сервісними центрами МВС України вважаємо за необхідне віднести: Конвенцію про дорожній рух [14], якою зокрема встановлено техніко-юридичні вимоги до національного та міжнародного водійського посвідчення (додатки 6, 7), а також умови їх видання (ст. 43); Європейську Угоду про міжнародне дорожнє перевезення небезпечних вантажів [15] - взаємозалежні між підписантами умови для перевезення небезпечних вантажів, які можуть бути предметом внутрішньодержавних або міжнародних розпоряджень, що стосуються в цілому дорожнього руху, міжнародних дорожніх перевезень або міжнародної торгівлі;

Центральне місце в механізмі правового регулювання займають закони України. Як слушно відмічає В.М. Самсонов, «закони регулюють найважливіші питання державного та суспільного життя, їх норми становлять фундамент, серцевину побудови та розвитку інших правових норм» [16, c. 55].

Титульним нормативно-правовим актом правових засад надання адміністративних послуг сервісними центрами МВС України необхідно визнати Закон України «Про адміністративні послуги», який визначає правові засади реалізації прав, свобод і законних інтересів фізичних та юридичних осіб у сфері надання адміністративних послуг [17]. Зокрема даним законодавчим актом визначено поняття адміністративних послуг та суб'єкту їх надання, закріплено перелік принципів державної політики у сфері надання адміністративних послуг, вимоги щодо якості надання адміністративних послуг, строки надання адміністративних послуг, порядок встановлення плати за надання адміністративних послуг, описано організаційні та процедурні аспекти надання адміністративних послуг тощо. 
До правових засад надання адміністративних послуг сервісними центрами МВС України можна також віднести Закон України «Про автомобільний транспорт» [18], яким зокрема визначено основи класифікації та реєстрації транспортних засобів (ст. 19), виписано вимоги до транспортних засобів і частин до них (ст. 20), правила міжнародних перевезень вантажів (ст. 53) тощо.

При розгляді правових засад надання адміністративних послуг сервісними центрами МВС України окремої уваги заслуговує також Закон України «Про дорожній рух» [19]. Саме названих правовим актом встановлено право кожного громадянина на керування транспортними засобами відповідної категорії, який досяг визначеного законом віку, не має медичних протипоказань та пройшов повний курс навчання за відповідними програмами (ч. 1 ст. 15).

Частиною 9 статті 15 Закону України «Про дорожній рух» встановлено, що «право на керування транспортними засобами відповідної категорії підтверджується посвідченням водія транспортного засобу з установленим терміном дії. На території України відповідно до Конвенції про дорожній рух діють національні та міжнародні посвідчення водія. Порядок видачі, обміну та встановлення терміну дії таких посвідчень визначається Кабінетом Міністрів України» [19]. Статтею 16 Закону України «Про дорожній рух» серед обов'язків водія передбачено: мати при собі та на вимогу уповноважених посадових осіб пред'являти для перевірки посвідчення водія, реєстраційний документ на транспортний засіб. Згідно інших положень нормативно-правових актів, про які мова піде нижче, саме сервісні центри МВС України надають адміністративну послугу з видачі відповідного посвідчення водія.

3 викладеного випливає, що описані положення визначають зміст обов'язків осіб, які мають бажання реалізувати право щодо керування транспортними засобами, а також загальні правила та умови його реалізації, кінцевим етапом яких необхідно вважати надання адміністративних послуг сервісними центрами МВС України.

Без перебільшення особливе значення для окреслення правових засад надання адміністративних послуг сервісними центрами МВС України має Закон України «Про перевезення небезпечних вантажів» [20]. Зокрема даним правовим документом надано визначення: небезпечного вантажу, небезпечних речовин, перевізника небезпечного вантажу, перевезення небезпечних вантажів, маршрутів перевезення небезпечних вантажів тощо.

Статтею 16 Закону України «Про перевезення небезпечних вантажів» визначено компетенцію Міністерства внутрішніх справ України, в межах якої передбачено зокрема «приймання іспитів та видача відповідних свідоцтв установленого зразка» [20].

Перелік вимог до транспортних засобів, якими перевозяться небезпечні вантажі, містить положення щодо необхідності «мати відповідне маркування і свідоцтво про допущення до перевезення небезпечних вантажів» [20] (ст. 19 закону України «Про перевезення небезпечних вантажів»).

Важливу роль серед правових засад надання адміністративних послуг сервісними центрами МВС України відіграють підзаконні норматив- 
но-правові акти. На відміну від законів - актів «первинного» характеру, що містять основоположні юридичні розпорядження, підзаконні нормативно-правові акти є «вторинними» документами, які конкретизують положення законів чи регламентують відносини, які не входять у предмет законодавчого регулювання.

Саме на підзаконному рівні правового регулювання забезпечено формування системи сервісних центрів МВС України у статусі юридичних осіб публічного права територіальних органів з надання сервісних послуг Міністерства внутрішніх справ України [21] (постанова Кабінету Міністрів України «Про утворення територіальних органів з надання сервісних послуг Міністерства внутрішніх справ» від 28.10.2015 № 889). Після прийняття Кабінетом Міністрів України постанови «Деякі питання територіальних органів Міністерства внутрішніх справ» від 12.02.2020 № 79 [22] зі статусом юридичної особи публічного права залишився лише Головний сервісний центр МВС як міжрегіональний територіальний орган з надання сервісних послуг МВС.

Окремі положення законів України, які нами розглянуто вище, деталізовані у межах:

1) Правил дорожнього руху, затверджених постановою Кабінету Міністрів України «Про Правила дорожнього руху» від 10.10.2001 № 1306, які «відповідно до Закону України «Про дорожній рух» встановлюють єдиний порядок дорожнього руху на всій території України. Інші нормативні акти, що стосуються особливостей дорожнього руху (перевезення спеціальних вантажів, експлуатація транспортних засобів окремих видів, рух на закритій території тощо), повинні грунтуватися на вимогах цих Правил» [23];

2) Порядку переобладнання транспортних засобів, затвердженому постановою Кабінету Міністрів України від 21.07.2010 № 607, який відповідно ч. 5 ст. 32 Закону України «Про дорожній рух» «визначає процедуру переобладнання транспортних засобів, призначених для експлуатації на вулично-дорожній мережі загального користування, що призводить до зміни повної маси та її розподілу по осях, розміщення центру ваги, типу двигуна, його ваги і потужності, колісної бази чи колісної формули, системи гальмового і рульового керування та трансмісії, зокрема для роботи на газовому моторному паливі та альтернативних видах рідкого і газового палива» [24].

3) постанови Кабінету Міністрів України від 16.09.2020 № 844 [25] 3 відповідними додатками, якою затверджено зразки та технічний опис бланків: національного посвідчення водія; міжнародного посвідчення водія; свідоцтва про реєстрацію транспортного засобу; тимчасового реєстраційного талона транспортного засобу, а також зразок розпізнавального автомобільного знака України;

4) Порядку надання фізичним та юридичним особам інформації $з$ Єдиного державного реєстру транспортних засобів стосовно зареєстрованих транспортних засобів, належних користувачів, затвердженому постановою Кабінету Міністрів України від 25.03.2016 № 260, який відповідно до ч.ч. 2, 3 ст. 34-1 Закону України «Про дорожній рух» «визначає механізм надання фізичним та юридичним особам інформації з Єдиного державного 
реєстру транспортних засобів стосовно зареєстрованих транспортних засобів, належних користувачів» [26];

5) Порядку підготовки, перепідготовки і підвищення кваліфікації водіїв транспортних засобів, затверджених постановою Кабінету Міністрів України від 20.05.2009 № 487, якою відповідно до ст. 15 Закону України «Про дорожній рух» визначено «процедуру підготовки, перепідготовки і підвищення кваліфікації водіїв транспортних засобів» [27];

6) Порядку проведення спеціального навчання працівників суб'єктів перевезення небезпечних вантажів, затвердженому постановою Кабінету Міністрів України від 31.10.2007 № 1285, який відповідно до ст. 11 Закону України «Про перевезення небезпечних вантажів» визначає однойменний організаційно-процедурний порядок [28] та інші нормативно-правові акти.

Підзаконний рівень правового регулювання надання адміністративних послуг сервісними центрами МВС України можна також охарактеризувати наявністю нормативно-правових актів, які регламентують питання, що не знайшли свого вирішення на законодавчому щаблі правового регулювання. Для прикладу можемо привести: Положення про порядок видачі посвідчень водія та допуску громадян до керування транспортними засобами, затверджене постановою Кабінету Міністрів України від 08.05.1993 № 340 [29].

Для більшості сучасних держав характерною $є$ наявність двох рівнів правового регулювання: 1) законодавчого та 2) іншого нормативного, включаючи і внутрішньовідомчий. Викладене рівною мірою має відношення до правової системи України. Зокрема, правові засади «не законодавчого» рівня правового регулювання надання адміністративних послуг сервісними центрами МВС України включають не лише нормативні документи Кабінету Міністрів України, а також правові акти відомчого рівня правового регулювання, які можуть прийматися Міністерством внутрішніх справ України, зокрема спільно з іншими центральними органами виконавчої влади, а також ГСЦ МВС.

Продовженням переліку титульних засад надання адміністративних послуг сервісними центрами МВС України можна знайти серед норм Положення про Головний сервісний центр МBC, затвердженого наказом МВС України від 07.11.2015 № 1393 (у редакції наказу МВС України від 24.04.2020 № 354) [30], лише зі змісту яких можна зробити висновок про те, що Головний сервісний центр МВС надає адміністративні послуги (п. 1 розд. II).

До інших нормативно-правових актів відомчого рівня правового регулювання, які забезпечують надання адміністративних послуг сервісними центрами МВС України для прикладу можна віднести наступні накази МВС України:

- «Про організацію доступу до відомостей персонально-довідкового обліку єдиної інформаційної системи Міністерства внутрішніх справ України» від 29.11.2016 № 1256 [31];

- «Про затвердження Інструкції щодо порядку формування коду платежу для оплати послуг» від 24.01.2019 № 43 [32];

- «Про затвердження технічних описів бланків документів, які видаються сервісними центрами МВС» від 31.08.2017 № 741 [33]; 
- «Про затвердження типових інформаційних карток адміністративних послуг, які надаються територіальним органом з надання сервісних послуг МВС» від 25.05.2020 № 409 [34];

- «Про затвердження Порядку реєстрації фізичних та юридичних осіб у системі керування чергою для отримання послуг, які надаються територіальними сервісними центрами МВС» від 05.11.2020 № 777 [35] тощо.

Як приклад міжвідомчого нормативно-правового регулювання надання адміністративних послуг сервісними центрами МВС України можна навести спільний наказ Міністерства внутрішніх справ України, Міністерства освіти і науки України, Міністерства інфраструктури України, Міністерства соціальної політики України від 05.04.2016 № 255/369/132/344, яким затверджено вимоги до закладів, що проводять підготовку, перепідготовку і підвищення кваліфікації водіїв транспортних засобів, та кваліфікаційних вимог до спеціалістів, які здійснюють таку підготовку [36].

Як ми вже відмічали, окремим напрямом відомчого нормативно-правового регулювання надання адміністративних послуг сервісними центрами МВС України необхідно вважати нормотворення на рівні Головного сервісного центру МВС. Наприклад, ГСЦ МВС з метою вдосконалення процесу прийняття іспитів для отримання права на керування транспортними засобами прийнято наказ від 16.06.2017 № 2, яким затверджено екзаменаційні білети для складення іспиту з теоретичної підготовки водіїв транспортних засобів [37].

Висновки. Як результат проведений нами аналіз правових засад надання адміністративних послуг сервісними центрами МВС України дає можливість охарактеризувати їх наступними ознаками (особливостями):

- визначають зміст діяльності сервісних центрів МВС України як складової сервісної функції держави;

- їх систему складають норми Конституції України, міжнародних правових актів, ратифікованих Верховною Радою України, законів України, підзаконних та відомчих нормативно-правових актів;

- мають дуалістичну природу, що проявляється у регулюванні суспільних відносин даної сфери нормами конституційного та адміністративного права, де визначальну роль стосовно практичного втілення сервісної функції держави відведено нормам саме адміністративного права;

- законодавчий рівень правового регулювання встановлює титульні засади щодо надання адміністративних послуг загалом та сервісними центрами МВС України зокрема, вимоги до окремих об'єктів адміністративних послуг, що надаються сервісними центрами МВС України, зміст прав та інтересів фізичних та юридичних осіб і умови їх реалізації, кінцевим етапом яких $\epsilon$ надання адміністративних послуг сервісними центрами МВС України;

- правові засади підзаконного рівня правового регулювання, уособлюючи норми правових актів Кабінету Міністрів України, конкретизують положення законів або регламентують відносини, які не входять до предмету законодавчого регулювання;

- нормативно-правові акти відомчого рівня правового регулювання (накази МВС України, спільні накази МВС України та інших центральних органів виконавчої влади, накази ГСЦ МBC), деталізуючи положення за- 
конів та підзаконних нормативних актів, переважно деталізують окремі аспекти процедур надання адміністративних послуг сервісними центрами МВС України;

- титульні правові засади поєднують положення законодавчого (Закон України «Про адміністративні послуги») та достатньо непослідовний «симбіоз» підзаконного (постанови КМ України від 28.10.2015 № 889 та від 12.02.2020 № 79) та відомчого (накази МВС України від 07.11.2015 № 1393 (у редакції наказу МВС України від 24.04.2020 № 354) рівнів правового регулювання.

Проведений нами аналіз правових засад надання адміністративних послуг сервісними центрами МВС України виступає основою для розкриття змісту їх окремих процедур, що ними надаються відповідними центрами та, як наслідок, напрацювання шляхів удосконалення адміністративно-правового регулювання таких процедур, що становить перспективний напрям наукових пошуків.

\section{СПИСОК ВИКОРИСТАНИХ ДЖЕРЕЛ}

1. Скакун О. Ф. Теорія государства и права : учебник Харків : Консул, 2000. $704 \mathrm{c}$.

2. Гетьман Є. Кодифікація як особливий різновид нормотворчості. Bicник Академії правових наук України. 2008. № 3 (54). С. 283-288.

3. Державне будівництво і місцеве самоврядування в Україні: підруч. для студентів ВНЗ / за ред. С. Г. Серьогіної. Харків: Право, 2005. 256 с.

4. Адміністративне право України : підручник. вид. 2, змін. і доп. / за заг. ред. Т.О. Коломоєць. Київ. : Істина, 2012. 528 с.

5. Шопіна I.М. Адміністративно-правове регулювання управління органами внутрішніх справ України : монографія / Ірина Миколаївна Шопіна. Київ: МП Леся, 2011. 426 с.

6. Голосніченко I. П. Адміністративне право України (основні категорії і поняття): посіб. для студентів ВНЗ / Держ. податк. адміністрація України, Укр. фінанс.-екон. ін-т, Юрид. ф-т. Ірпінь : Укр. фінанс.-екон. ін-т ДПА України, 1998. 112 с.

7. Курс адміністративного права України: підручник / заред. В. В. Коваленко. Київ : Юрінком Інтер, 2012808 с.

8. Заброда Д. Г. Адміністративно-правові засади: сутність та зміст категорії. Адміністративне право і процес. 2013. № 2 (4). С. 45-51

9. Негодченко В.О. Адміністративно-правове забезпечення державної інформаційної політики органами Національної поліції України: монографія. Харків : Харківський національний університет внутрішніх справ, 2016. 544 c.

10. Золотько О. О. Правове регулювання діяльності підрозділів ветеринарної міліції щодо профілактики та ліквідації наслідків епізоотичних ситуацій. Право і Безпека. 2011. № 3. С. 106-111

11. Теорія держави та права : підручник / Є.О. Гіда, Є.В. Білозьоров, А.М. Завальний та ін.; за заг. ред. Є.О. Гіди. Київ. : ФОП О. С. Ліпкан, 2011. $576 \mathrm{c}$.

12. Конституція України : закон України від 28.06.1996 № 254к/96-BP. 
13. Мельник Р. С., Бевзенко В. М. Загальне адміністративне право : навчальний посібник / за заг. ред. Р. С. Мельника. Київ : Ваіте, 2014. 376 с.

14. Конвенція про дорожній рух : міжнародний документ від 08.11.1968 (консолідована версія станом на 26.03.2006).

15. Європейська Угода про міжнародне дорожнє перевезення небезпечних вантажів : міжнародний документ від 30.09.1957, приєднання згідно закону України від 02.03.2000 № 1511-III.

16. Самсонов В. Н. Административное законодательство: понятие, содержание, реформа. Харків, 1991. 120 с.

17. Про міжнародні договори України : закон України від 06.09.2012 № 5203 -VI.

18. Про автомобільний транспорт : закон України від 05.04.2001 № 2344-III.

19. Про дорожній рух : закон України від 30.06.1993 № 3353-XII.

20. Про перевезення небезпечних вантажів : закон України від 06.04.2000 № 1644-III.

21. Про утворення територіальних органів з надання сервісних послуг Міністерства внутрішніх справ : постанова Кабінету Міністрів України від 28.10.2015 № 889.

22. Деякі питання територіальних органів Міністерства внутрішніх справ : постанова Кабінету Міністрів України від 12.02.2020 № 79.

23. Про правила дорожнього руху : постанова Кабінету Міністрів України від 10.10.2001 № 1306.

24. Про затвердження Порядку переобладнання транспортних засобів : постанова Кабінету Міністрів України від 21.07.2010 № 607.

25. Про затвердження зразків бланків і технічних описів бланків національного та міжнародного посвідчень водія, свідоцтва про реєстрацію транспортного засобу, тимчасового реєстраційного талона транспортного засобу та зразка розпізнавального автомобільного знака України та внесення змін до деяких постанов Кабінету Міністрів України : постанова Кабінету Міністрів України від 16.09.2020 № 844.

26. Деякі питання надання інформації про зареєстровані транспортні засоби, їх власників та належних користувачів : постанова Кабінету Міністрів України від 25.03.2016 № 260.

27. Про затвердження Порядку підготовки, перепідготовки і підвищення кваліфікації водіїв транспортних засобів постанова Кабінету Міністрів України від 20.05.2016 № 487.

28. Про затвердження Порядку проведення спеціального навчання працівників суб’єктів перевезення небезпечних вантажів : постанова Кабінету Міністрів України від 31.10.2007 № 1285.

29. Про затвердження Положення про порядок видачі посвідчень водія та допуску громадян до керування транспортними засобами : постанова Кабінету Міністрів України від 08.05.1993 № 340.

30. Про внесення змін до Положення про Головний сервісний центр МBC : наказ МВС України від 24.04.2020 № 354.

31. Про організацію доступу до відомостей персонально-довідкового обліку єдиної інформаційної системи Міністерства внутрішніх справ України : наказ МВС України від 29.11.2016 № 1256. 
32. Про затвердження Інструкції щодо порядку формування коду платежу для оплати послуг : наказ МВС України від 24.01.2019 № 43.

33. Про затвердження технічних описів бланків документів, які видаються сервісними центрами МВС : наказ МВС України від 31.08.2017 № 741.

34. Про затвердження типових інформаційних карток адміністративних послуг, які надаються територіальним органом з надання сервісних послуг МВС : наказ МВС України від 25.05.2020 № 409.

35. Про затвердження Порядку реєстрації фізичних та юридичних осіб у системі керування чергою для отримання послуг, які надаються територіальними сервісними центрами МВС : наказ МВС України від 05.11.2020 № 777.

36. Про затвердження Вимог до закладів, що проводять підготовку, перепідготовку і підвищення кваліфікації водіїв транспортних засобів, та кваліфікаційних вимог до спеціалістів, які здійснюють таку підготовку : наказ МВС України, МОН України, Мінінфраструктури України, Мінсоцполітики України від 05.04.2016 № 225/369/132/344.

37. Про затвердження екзаменаційних білетів для складення іспиту з теоретичної підготовки водіїв транспортних засобів : наказ ГСЦ МВС від 16.06.2017 № 2 .

\section{O. Kniaziuk}

\section{FEATURES OF LEGAL PRINCIPLES OF PROVISION OF ADMINISTRATIVE SERVICES BY SERVICE CENTERS OF THE MINISTRY OF INTERNAL AFFAIRS OF UKRAINE}

It is noted that the creation of service centers of the Ministry of Internal Affairs of Ukraine was one of the areas of reforming the internal affairs bodies. At the same time, the relatively short existence of the latter necessitates an assessment of the current state of the legal framework for the provision of administrative services by the relevant centers. The author pays direct attention to the theoretical foundations of understanding the categories «legal framework», "legal framework», «legal regulation», "administrative-legal regulation», "administrative-legal framework». The article considers the content of regulations governing public relations in the field of administrative services by service centers of the Ministry of Internal Affairs of Ukraine depending on the level of their legal regulation: legislative, bylaw, departmental. As a result, the analysis of the legal basis for the provision of administrative services by service centers of the Ministry of Internal Affairs of Ukraine provided an opportunity to characterize them with the following features (features): determine the content of service centers of the Ministry of Internal Affairs of Ukraine as part of the service function; their system consists of the norms of the Constitution of Ukraine, international legal acts ratified by the Verkhovna Rada of Ukraine, laws of Ukraine, by-laws and departmental normative legal acts; have a dualistic nature, which is manifested in the regulation of social relations in this area by the rules of constitutional and administrative law; The legislative level of legal regulation establishes the title principles for the provision of administrative services in general and service centers of the Ministry of Internal Affairs of Ukraine in particular, requirements for certain objects of administrative services provided 
by service centers of the Ministry of Internal Affairs of Ukraine. which are the provision of administrative services by service centers of the Ministry of Internal Affairs of Ukraine; legal principles of the bylaw level of legal regulation, embodying the norms of legal acts of the Cabinet of Ministers of Ukraine, specify the provisions of laws or regulate relations that are not included in the subject of legislative regulation; normative legal acts of the departmental level of legal regulation mainly detail certain aspects of the procedures for providing administrative services by the service centers of the Ministry of Internal Affairs of Ukraine; title legal bases combine the provisions of the legislative and rather inconsistent «symbiosis» of bylaws and departmental levels of legal regulation.

Keywords: legal bases, legal regulation, administrative-legal regulation, norms of law, service centers of the Ministry of Internal Affairs of Ukraine. 